\title{
Uranium migration history in the igneous and metamorphic rocks of Solaf-Umm Takha area, based on multi-variate statistical analysis and favorability indices, central south Sinai, Egypt.
}

\author{
Tamer E. Attia ${ }^{1 \& 2}$ and El-Arabi H. Shendi ${ }^{3}$ \\ ${ }^{1}$ Geology Department, Faculty of science, Port Said University, Port Said, Egypt \\ ${ }^{2}$ Earth Science Department, Faculty of Science, Benghazi University, Benghazi, Libya \\ ${ }^{3}$ Geology Department, Faculty of science, Suez Canal University, Ismailia, Egypt
}

\begin{abstract}
The present study deals with the application of three different analytical techniques on the recorded ground gamma ray spectrometric measurements in order to detect the radioelements content specially Uranium in Solaf-Umm Takha area, south Sinai, Egypt. These techniques include Uranium migration (in and out), Uranium favorability index and multi-variate statistical analysis including first and second principal component and factor scores. The obtained results have indicated that Umm Takha granite and the quartzo - feldspathic gneiss as well as the El-Sheikh granite are Uranium source rocks with low favorability indices. However the application of favorability index technique has proved to be an effective tool in igneous and metamorphic environments to indicate Uranium depletion from source rocks. The integration of original uranium content, uranium migration rate and Uranium favorability index indicated that Uranium migrated from the eastern and southern parts and has been ultimately accumulated in the western and northern parts of the study area. Topographically, uranium has been migrated from the high relief mountainous region to the drainage divide of Solaf-Umm Takha valleys. Therefore, uranium migration history proves its validity in distinction between syngentically-mineralized source rocks and secondary enriched rocks in the investigated area.

Keywords : factor scores, favorability indices, Sinai, spectrometry and uranium migration.
\end{abstract}

\section{INTRODUCTION}

The investigation of the aero-radiometric map of southwestern Sinai (Fig.1) [1] has suggested a promising area for further detailed ground gamma ray spectrometric studies. This area, known as Solaf-Umm Takha area, is bounded by longitudes $33^{\circ} 41^{\prime} 14^{\prime \prime}$ and $33^{\circ} 44^{\prime} 10^{\prime \prime} \mathrm{E}$ and latitudes $28^{\circ} 36^{\prime} 39^{\prime \prime}$ and $28^{\circ} 38^{\prime} 35^{\prime \prime} \mathrm{N}$, and is about $17.325 \mathrm{Km}^{2}$ in area (Fig.2).

The gamma-ray spectrometric method is a powerful tool in geological mapping. It is possible, when using this method, to determine the individual concentrations of the three naturally-occurring radioelements in the ground. The method depends upon the fact that the absolute and relative concentrations of the radioelements $(\mathrm{K}, \mathrm{U}$, and $\mathrm{Th})$ vary measurably and significantly with lithology [2].

In this study, three different analytical techniques have been applied on the measured ground gamma ray spectrometric data in an attempt to locate the different distributions of radioelements. These techniques are the uranium migration, the multi-variate statistical analysis and favorability indices. The favorability indices have been applied in order to trace the migration history of uranium in the study area.

\section{Geological And Structural Outline}

The first description of Feiran-Solaf metamorphic complex geology was done in the west Sinai gneisses extended as a strip $200 \mathrm{Km}$ long and $8 \mathrm{Km}$ wide and considered the gneisses of Wadi Feiran to be fragments of much older continental crust. Further, he concluded that the granitic masses induced metamorphic

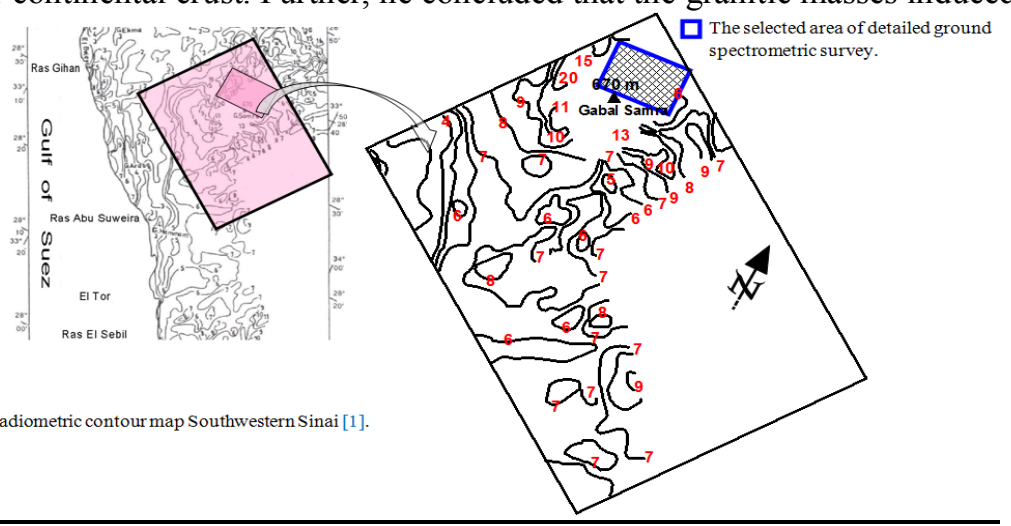




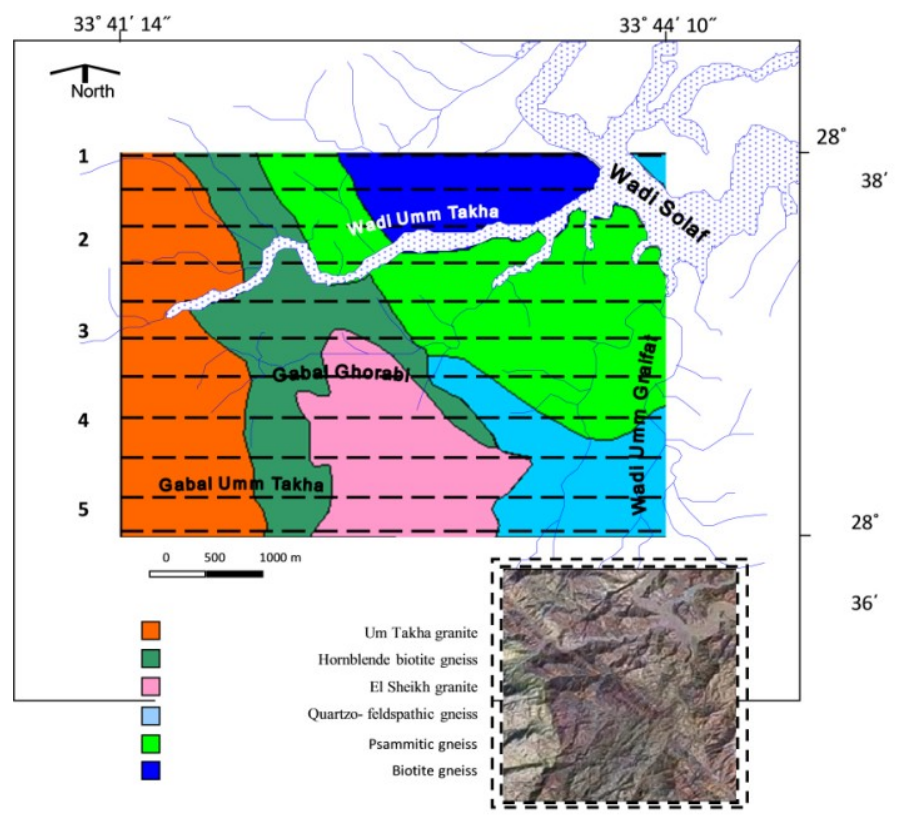

Fig.2: Geologic map of Solaf-Umm Takha area on which the ground spectrometric profiles are located.

changes in sedimentary rocks, with the granites themselves being deformed into gneiss [3] and [4]. Different varieties of gneisses from south Sinai are of Archean age and had been subjected to high degrees of metamorphism [5]. Also showed the megmatite complex around Feiran Oasis comprises hornblende biotite feldspar gneiss and biotite feldspar quartz of quartz-dioritic to granodioritic composition [6]. Less common types correspond to diorites and granite. The Feiran-Solaf gneiss belt represents a thick geosynclinal sedimentary succession, with minor basic intercalations, regionally metamorphosed and variably granitized. The belt is bounded from both sides by a number of granitic intrusions. This succession was folded into three anticlines separated by a thrust fault and metamorphosed into gneisses and migmatites and this folding initiated just prior to regional metamorphism and granitization. [7], [8] and [9] They also found that the high grad metamorphism took place and affected the gneiss belt through two stages belonging to one cycle of metamorphism and no tectonic events have intervened between them. The rock units can be arranged from old to young according to [10] as follows:

1- Biotite gneiss interbanded with hornblende biotite gneiss.

2- Psammitic gneiss.

3- Medium - grained quartzo-feldspathic gneiss with fine-grained hornblende biotite gneiss intercalations.

4- Medium-grained hornblende biotite gneiss with garnetiferous biotite gneiss.

5- El-Sheikh granite.

6- Umm Takha granite.

Structurally, the gneisses reached their present situation through two phases of metamorphism accompanied by two phases of deformation. The area is dominated by three folding systems of alternating and superimposing anticlines and synclines which have a great role in the spatial distribution of the different rock units in the study area [10].

Hornblende biotite gneisses are fine to medium grained, strongly foliated and dark colors. They are intercalated and interlayered with the biotite and the quartzo-feldspathic gneisses. Also field relations clearly showed that the hornblende biotite gneisses are older than both. White granodioritic outcropped at the upstream end of Wadi Umm Takha where it is intruded by the alkali red granites of Gabel Serbal [11].

Solaf gneiss reached its present tectonic setting through two main progressive deformational events D1 and D2 Accordingly, four macroscopic folding generations are detected in the following trends NW-SE and NE-SW [12]. In addition to the quartzo-feldspathic gneiss and mylonite rocks of west Wadi Hebran -Umm Graifat area are strongly sheared leucocratic rocks [13].

\section{Acquisition Of Ground Gamma-Ray Spectrometric Data}

Ground follow up of the aero-radiometric anomalies has been carried out in Solaf-Umm Takha area in an attempt to figure out the distribution of radioelements, especially uranium, in the different rock types and to determine which type of rocks is attractive for uranium. Detailed ground spectrometric surveying was conducted in this study by using a portable gamma-ray spectrometer (SCINTREX model GAD-6), digital four channel spectrometer designed for use with a range of Scintrex gamma-ray sensors. It is of the same basic design as its 
successful predecessor; the GAD-6 which can provide quantitative analysis for $\mathrm{K}, \mathrm{U}$ and Th content in outcrop, drill hole, laboratory, mobile ground or airborne survey applications [14]. The energy Peaks of uranium, thorium measurements are $(1.76 \mathrm{MeV}$ from $214 \mathrm{Bi})$ and $(2.61 \mathrm{MeV}$ from $208 \mathrm{Tl})$ respectively and potassium was measured directly from the $1.46 \mathrm{MeV}$ emitted by $\mathrm{K}^{40}$. Artificial concrete calibration pads of blank, potassium; uranium and thorium of Canadian style were used to calibrate the spectrometer [15]. The obtained calibration values (including background and stripping corrections) were later used to correct the field GAD-6 measurements and convert them into radioelement concentrations ( $\mathrm{U}$ and $\mathrm{Th}$ in ppm and $\mathrm{K}^{40}$ in \%) [16].

In the study area, the field measurements were recorded above 374 stations, along 11 parallel profiles striking in the E-W direction (Fig.2), crossing all the different rock unites. The distance separation between successive profiles was $350 \mathrm{~m}$ and between successive stations was $150 \mathrm{~m}$. The lowest recorded readings in the potassium, uranium and thorium channels were considered to be the background values in the study area. These readings were found as being $106.91,46.8$, and $8.9 \mathrm{cps}$ respectively.

The corrected total count gamma ray measurements were converted into units of radioelements concentration (Ur), recommended by the [16]. Further, the recorded radiometric measurements in the other three channels were converted into concentrations of radioelements, $\mathrm{K}$ in \%, equivalent uranium, (eU) in ppm, and equivalent thorium, (eTh) in ppm. The results are then represented in contour maps for total counts of uranium, thorium and potassium.

\section{Results And Discussion}

The corrected field spectrometric measurements were represented in the form of contour maps showing the spatial distribution features of the apparent and relative surface concentrations of the three radioelements K, $\mathrm{U}, \mathrm{Th}$, in addition to the integral gamma ray response (T.C.) of the study area. These maps will be elucidated in the following:

\section{a- Total Count (T.C.) map:}

The T.C. map (Fig.3), of the Solaf-Umm Takha area shows a wide variation of radioactivity from 55 to 133 Ur, which reflects the various rock compositions in the study area. Five anomalous sites could be detected all over the area. Their values vary between 103 and 133 Ur. These anomalies have different directions. The rock units hosting these anomalies are psammitic gneiss, biotite gneiss, hornblende biotite gneiss, quartzofeldspathic gneiss and El-Sheikh granite.

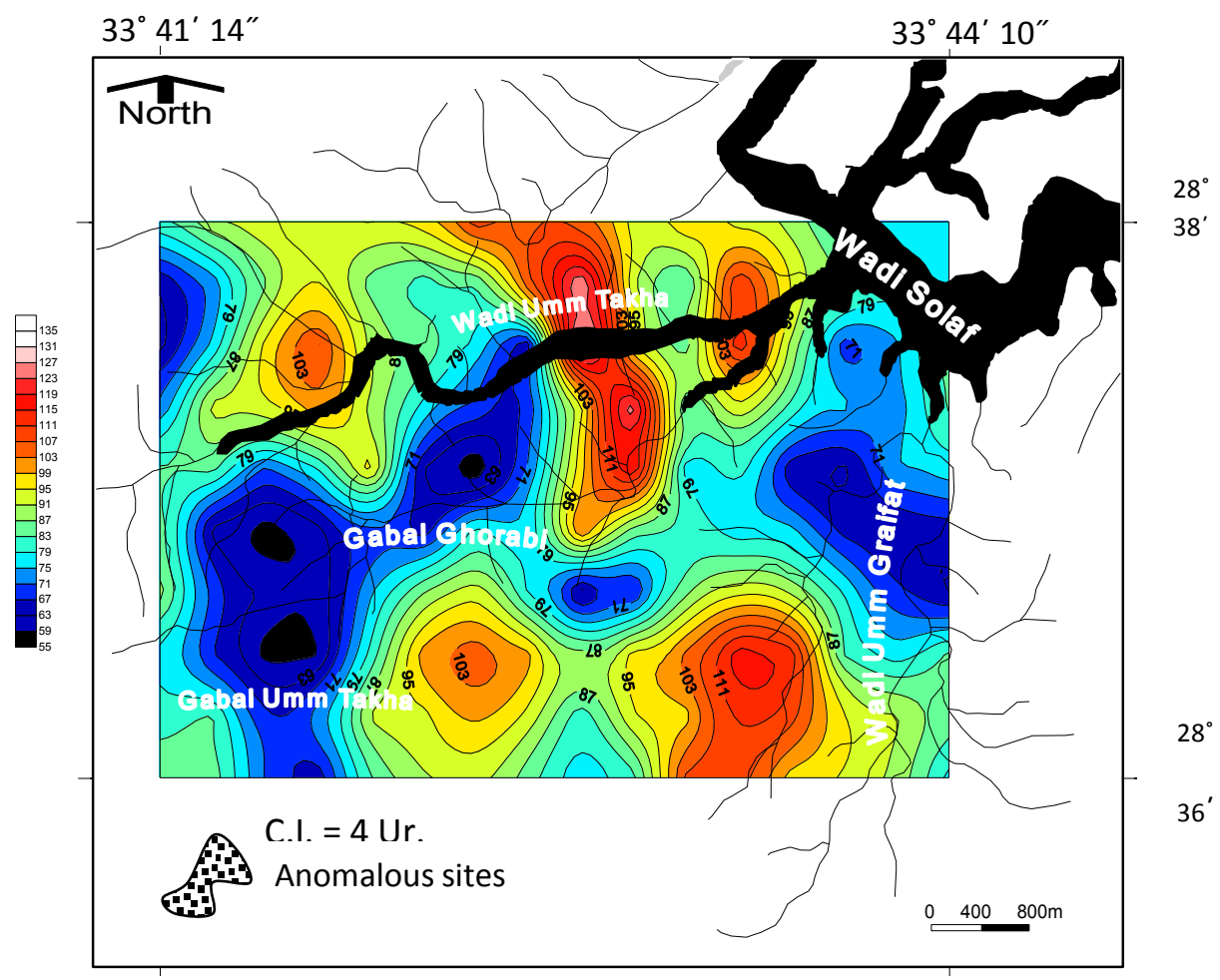

Fig.3: T.C. contour map of Solaf-Umm Takha area. It shows a wide variation of radioactivity from 55 to $133 \mathrm{Ur}$, which reflects the various rock compositions in the study area. Five anomalous sites could be detected all over the area. Their values vary between 103 and 133 Ur. 
b- Potassium concentration (K \%) map

The contour map of the potassium concentration (Fig.4) is very similar to that of the total count map. The high potassium anomalies values range from 2.1 to $3.6 \%$, and occupy nearly the same sites as the T.C. anomalies except the El-Sheik granite unit.

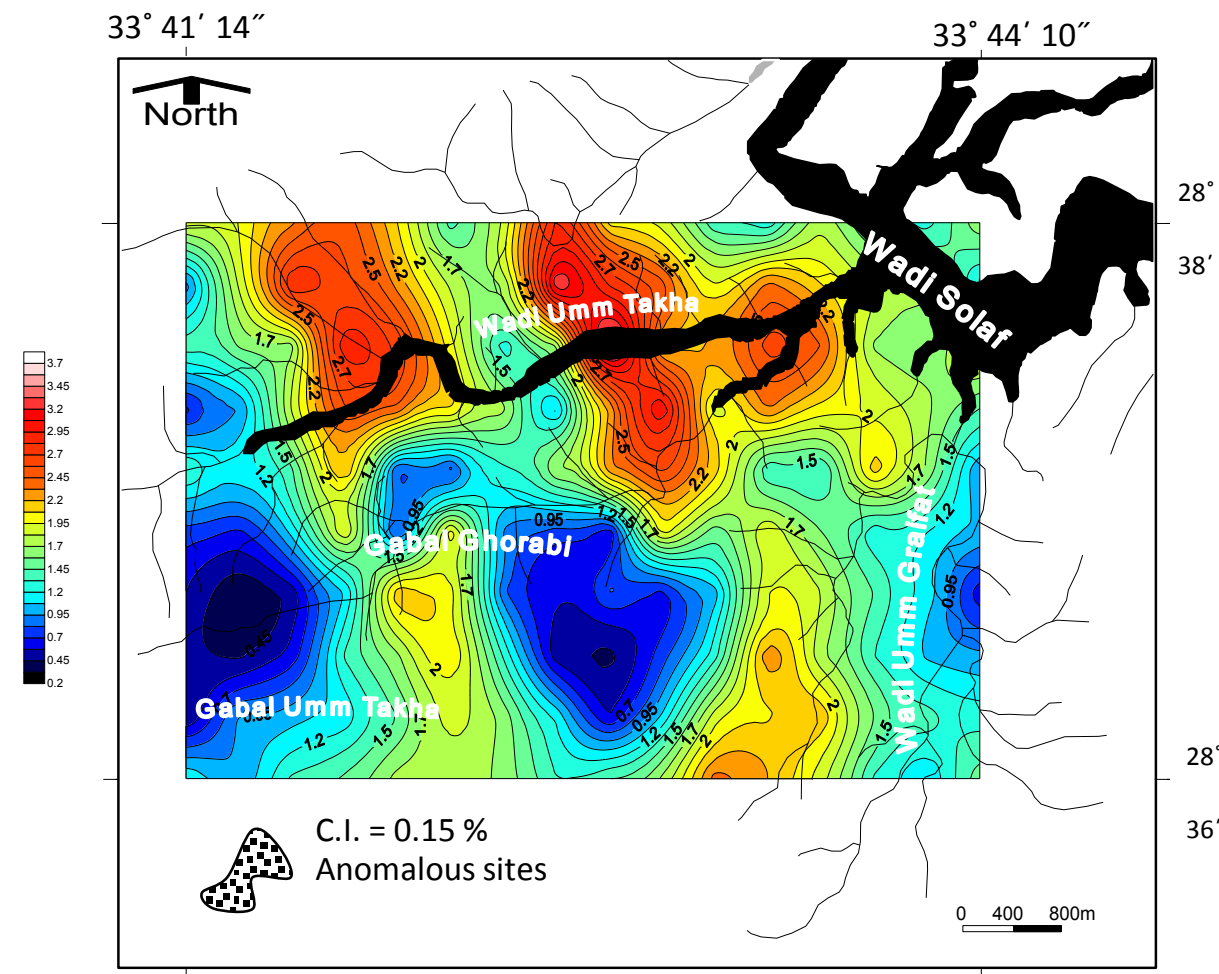

Fig.4: $\mathrm{K} \%$ contour map of Solaf-Umm Takha area is very similar to that of the total count map. The high Potassium anomalies have values ranging from 2.1 to $3.6 \%$.

c- Equivalent uranium (eU) map

The eU map of the study area (Fig.5) also shows five major closures of high uranium readings ranging in values from 2.8 to $4 \mathrm{ppm}$. These high readings coincide mostly with the high readings in both of the T.C. and $\mathrm{K} \%$ maps. It is also evident that the high uranium values are somewhat evenly distributed among the different rock types in the study area (Figs 2 and 5). This distribution is mainly attributed to the high mobility of uranium. This range of anomalous values is pretty much consistent with the average abundance of uranium in metamorphic basement rocks (3.5 ppm U) and granite (4.5 ppm U) [17].

\section{d- Equivalent Thorium (eTh) map}

The eTh contour map of the study area (Fig.6) contains more than ten high anomalies with steep gradients, occupying nearly $60 \%$ of the study area and ranging in values from 7.5 to $12.5 \mathrm{ppm}$. Some of these anomalies coincide with the uranium anomalous sites and others do not, which confirm the immobility behavior of thorium.

\section{Uranium Accumulation And Migration}

There are two key processes in uranium accumulation; the uranium migration and the uranium dispersion in the oxidized zone. In the uranium migration, uranium occurs in nature in two oxidation states: U+4 and U+6 whose ionic radii are $1.05 \AA$ and $0.83 \AA$, respectively. In the igneous and metamorphic environment, Uranium is mobile in the reduced state and tends to accumulate in the late differentiation of igneous melt. The two radioelements Uranium and Thorium have the same ionic radii and bond character and also form at the same conditions in the magma chamber. This explains why they tend to occur together in igneous rocks and hydrothermal ore deposits that form at high temperature. With regard to the second processes: while uranium is a mobile radioelement and migrates under the action of oxygen from the ground water during its evolution and accumulation, thorium is a relatively stable radioelement in the oxidation zone. As a result, breaking the original (U-Th formed state) is indicated by the presence of high-Th site, which could be recommended as the original U- high area [17]. Granitic bodies that are greatly enriched in Th and their associated elements are generally the high level postorogenic intrusive types. 


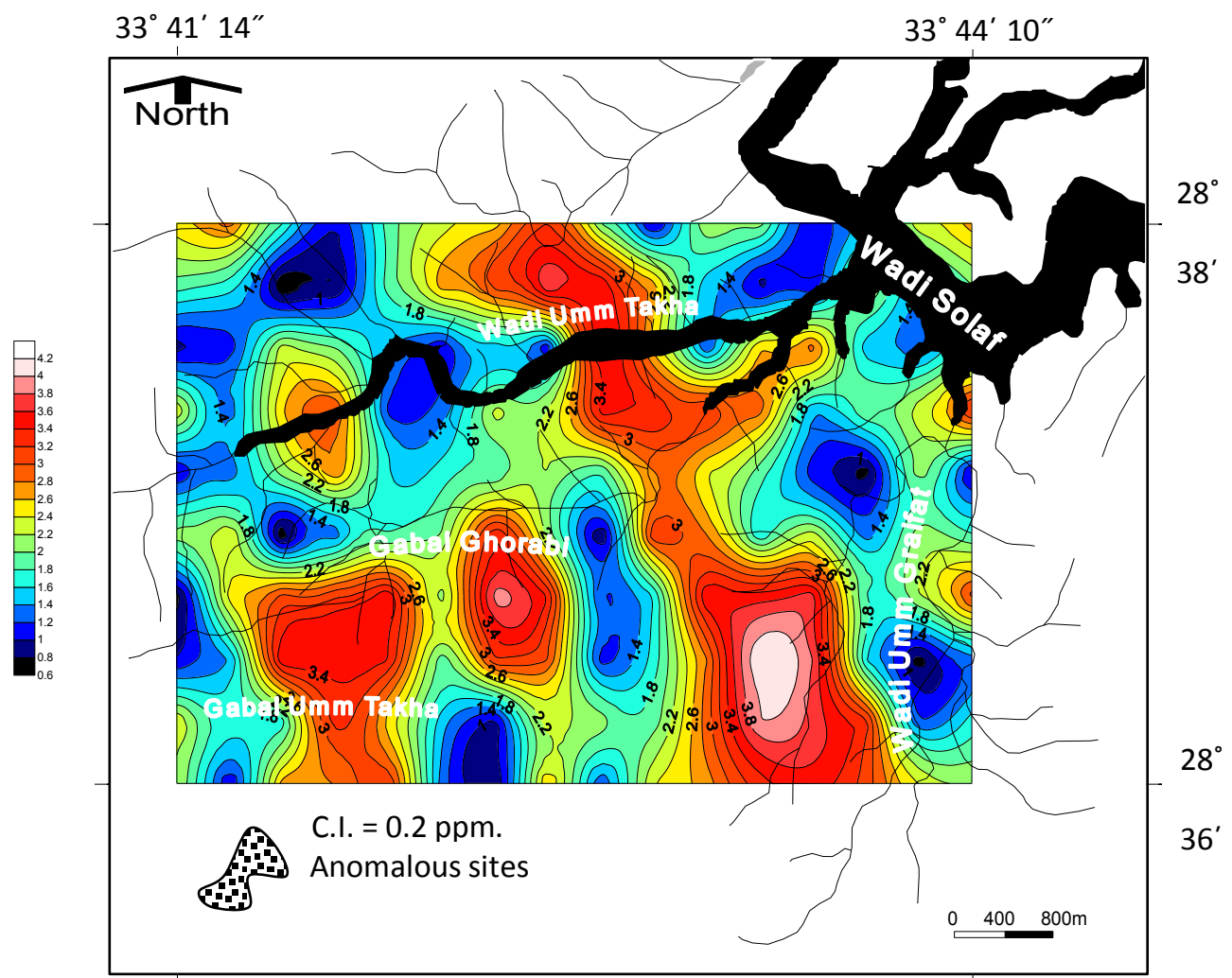

Fig.5: eU contour map of Solaf-Umm Takha area. It shows five major closures of high Uranium readings ranging in values from 2.8 to $4 \mathrm{ppm}$. These high readings coincide mostly with the high readings in each T.C. and $\mathrm{K} \%$ maps.

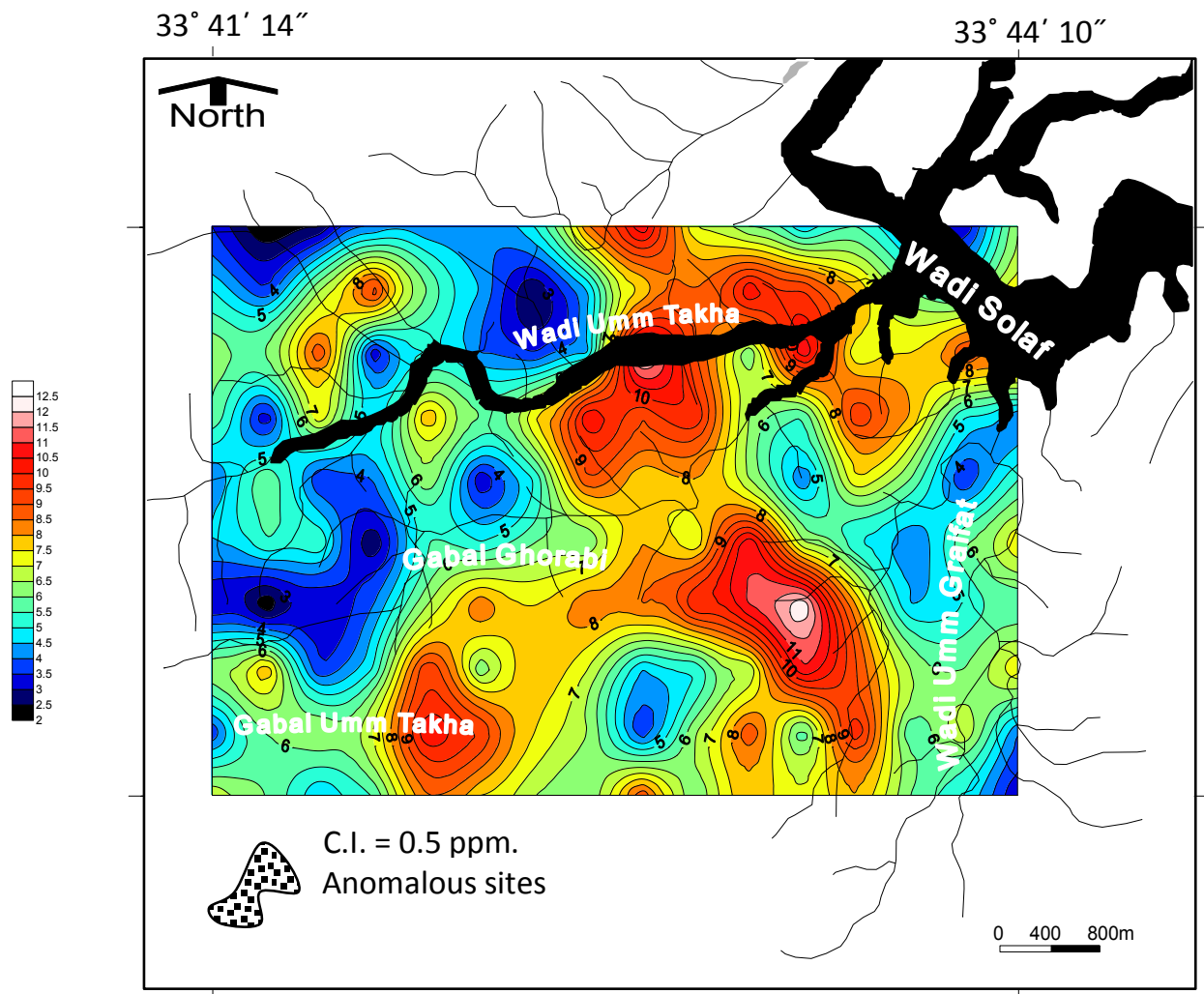

Fig.6: eTh contour map of Solaf-Umm Takha area. It contains more than ten high anomalies with steep gradients, occupying nearly $60 \%$ of the study area and ranging in values from 7.5 to $12.5 \mathrm{ppm}$. 
Most of the enriched granites are not of commercial importance at present but provide a large reserve of thorium and uranium for the future as some contain up to $240 \mathrm{ppm}$ Th and $120 \mathrm{ppm} \mathrm{U}$ [18]. Consequently, the second process is concluded to be the most fundamental in the distribution of these two radioelements.

The eU/eTh ratio is a very important geochemical parameter in the migration of ranium. This ratio is highly affected by the oxidation processes that can lead to uranium migration and consequently its loss or gain. This ratio is an important parameter in determining the oxidizing environment in which uranium was transported [19]. It is considered approximately constant for each rock type in closed environment (Equilibrium Uranium series ). Accordingly, if the uranium migrates out or in during the broken environment state, this standard ratio will be changed for each geologic unit. The analysis of uranium migration is illustrated by the following mathematical equations [20] and examined in Egypt by [21], [22] and [23].

$$
U_{0}=e \overline{T h} * \frac{\overline{e U}}{\overline{e T h}}
$$

Where $U_{0}$ is the original uranium content, eTh is the average of the equivalent thorium content in certain geological unit in ppm and eU/eTh is the average of regional eU/eTh ratio in different geological units.

$$
U_{m}=U_{P}-U_{0}
$$

Where, $U_{m}$ is the amount of uranium migration. $U_{P}$ is the present uranium content.

$$
P=\frac{U_{m}}{U_{P}} * 100
$$

Where, $P$ is the uranium migration rate.

There are two states of uranium migration which are: $U_{m}>0$ which reflects uranium migration in the geologic rock unit, and $U_{m}<0$ which reflects uranium migration out the geologic rock unit.

In the study area, the average values of eU, eTh and $\mathrm{K} \%$ are computed for the different rock units (Table.1).According to these values, three geological rock units in the study area have been identified as uranium-source rocks, which are Umm Takha granite, Quartzo-feldspathic gneiss and El-Sheikh granite. They have negative amounts of uranium migration (-0.11, -0.05 and $-0.01 \mathrm{ppm}$ respectively).

Further, this table shows that the Umm Takha granite has the highest uranium outward migration with the migration rate of about (-5.53\%). This high rate of migration may indicate that the Umm Takha granite is the main uranium-source rock in the study area. The other three rock units (i.e. psammitic gneiss, hornblende biotite gneiss and biotite gneiss) are contaminated by Uranium accumulations. These rocks show positive values of uranium inward migration $(0.07,0.01 \& 0.007 \mathrm{ppm}$ respectively). However the psammitic gneiss rocks have the highest uranium inward migration with the migration rate of about $(3.15 \%)$. This rate of migration strongly implies that this rock is the main uranium-received rock in the study area.

Uranium migration model was developed in hard rocks and at the same time the blind predictions are used to drive the experimental program, as they help to identify data needs and data gaps [24]. This experiment demonstrated that uranium can migrate over very short timescales, at appreciable concentrations and this is obviously more difficult with field investigations, although an understanding of secondary uranium phase formation permits defensible conclusions to be drawn on the effectiveness of host rock retardation (received rocks).

Accordingly, this conclusion may be satisfied geologically by many authors as mentioned before in the geological and structural settings section which demonstrated that the psammitic gneiss rock as one of the oldest rock units in the study area. In addition to the structural control which influenced the pathway of leached uranium from the massive granitic source rocks to its accumulation in the psammitic gneiss received rocks along the sides of the main stream Wadi of Umm Takha.

b- Uranium favorability index:

Three indices, designated as $\mathrm{U}_{1}, \mathrm{U}_{2}$, and $\mathrm{U}_{3}$, based on examination of aerial radiometric data of Alaska [25], [26] and [27]. They reasoned that favorable areas will have an elevated radioelement content characterized by high mean eU, eTh, and $\mathrm{K}$ values, and high coefficients of variation for these elements and the ratios eU/eTh and $\mathrm{eU} / \mathrm{K}$. Furthermore, if leaching or depletion of uranium in source rocks has actually occurred, then favorable areas should be characterized by low mean values of eU/eTh and eU/K. $U_{1}, U_{2}$, and $U_{3}$ are constructed to give increasing index values with increasing uranium favorability. $\mathrm{U}_{1}$ is defined as the ratio of all increasing parameters to all decreasing parameters, or

$$
U_{1}=\frac{(M e U+M e T h+M K) \cdot R S D(e U) \cdot R S D(e U / e T h) \cdot R S D(e U / K)}{M(e U / e T h) \cdot M(e U / K)}
$$

Where $\mathrm{M}$ designates mean quadrangle value, and RSD designates the relative standard deviation of the quadrangle. $\mathrm{U}_{2}$ is defined as a similar ratio, 


$$
U_{2}=\frac{M e U}{(M e U / M e T h) \cdot(M e U / M K)}=\frac{M e T h \cdot M K}{M e U}
$$

In order to avoid soil moisture and vegetation effects, U3 is defined as the reciprocal of ratio products, or regarded $\mathrm{U}_{2}$ as the best of the three because it most effectively separates top-ranged quadrangles [25].

$$
U_{3}=\frac{1}{(M e U / M e T h) \cdot(M e U / M K)}=\frac{M e T h \cdot M K}{(M e U)^{2}}
$$

Thorium is used as a "surrogate" of original uranium content because of the contrast in mobility of uranium and thorium under oxidizing conditions. The ration $\mathrm{eTh} / \mathrm{eU}$ is expected to be high if uranium depletion has actually occurred. Source units, therefore, will have high values of both parameters. A major criticism of $\mathrm{U} 1, \mathrm{U} 2$, and $\mathrm{U} 3$ is found in the use of quadrangle means of the various parameters. Interpreting such values is difficult, especially for ratios such as eU/eTh. In particular, interpreting low values of eU/eTh to indicate uranium depletion from source rocks may be partly true in sedimentary terrains, but fractionation may invalidate such an interpretation in igneous and metamorphic terrains. Combining all lithology to construct a quadrangle mean obscures the situation even more [28] and [29].

But, in the study area this is not true, because the source rocks of Uranium (Uranium migrated out) such as Umm Takha granite, quartzo-feldspathic gneiss and El-Sheikh granite have the lower uranium favorability indices, while the received rocks of uranium (uranium migrated in) such as psammitic gneiss, hornblende biotite gneiss and biotite gneiss have the higher uranium favorability indices (Table 1). That means the results refer to the obvious general observation concluded from figs. (7\&8) in this area as a whole, whenever migration attains a high value (i.e. the rock is depleted from $\mathrm{U}$ ) the uranium favorability index becomes low and vice versa. So, interpreting low values of eU/eTh which indicate uranium depletion from source rocks may validate such an interpretation in igneous and metamorphic terrains.

Table 1: Statistics for Uranium migration, migration rate and Uranium favorability index in different rock units in the study area.

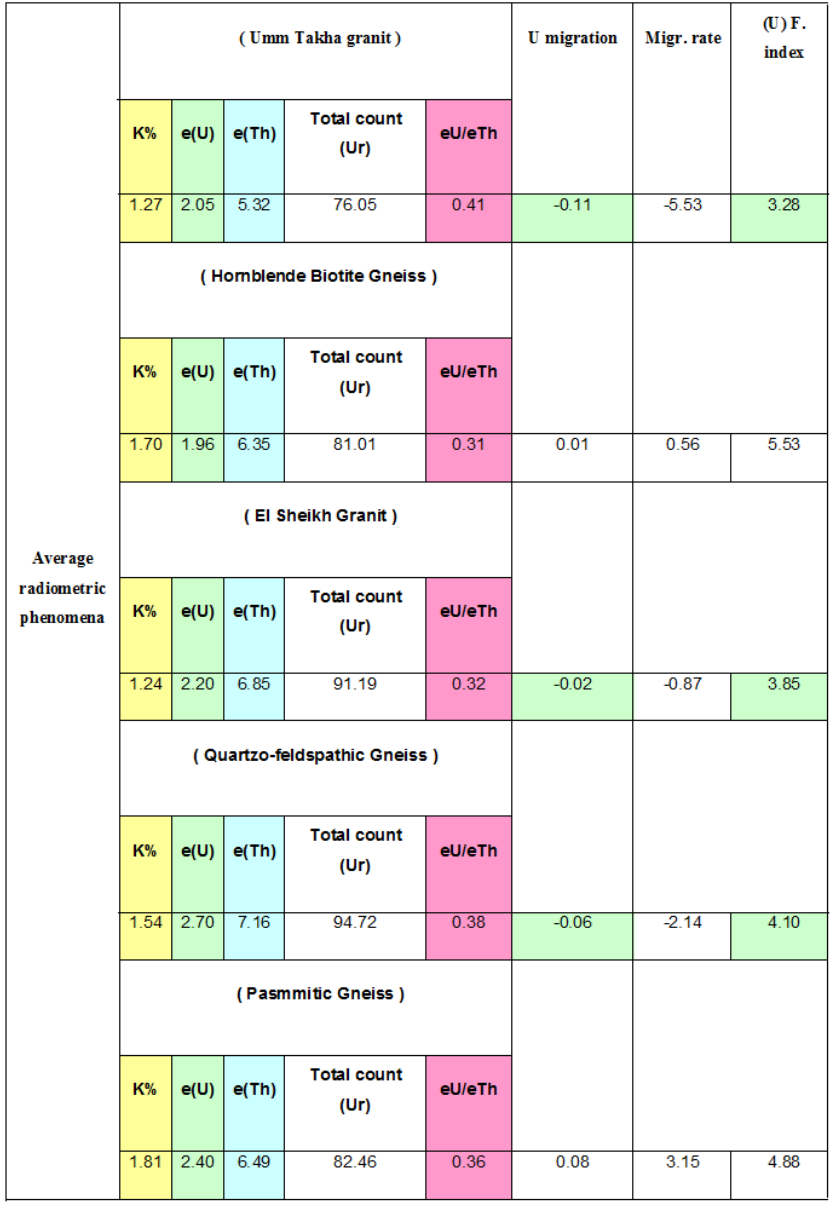


Fig 7: Uranium migration diagram for all geologic rock units in the study area, where the source rocks of Uranium (Uranium migrated out) such as (Umm Takha granite, Quartzofeldspathic gneiss and El-Sheikh granite), while the received rocks of Uranium (Uranium migrated in) such as Psammitic gneiss, Hornblende biotite gneiss and Biotite gneiss.

Fig 8: Uranium favorability index diagram for all geologic rock units in the study area, where the source rocks of Uranium such as (Umm Takha granite, Quartzo-feldspathic gneiss and El-Sheikh granite) have the lower Uranium favorability indices, while the received rocks of Uranium such as Psammitic gneiss, Hornblende biotite gneiss and Biotite gneiss have the higher Uranium favorability indices
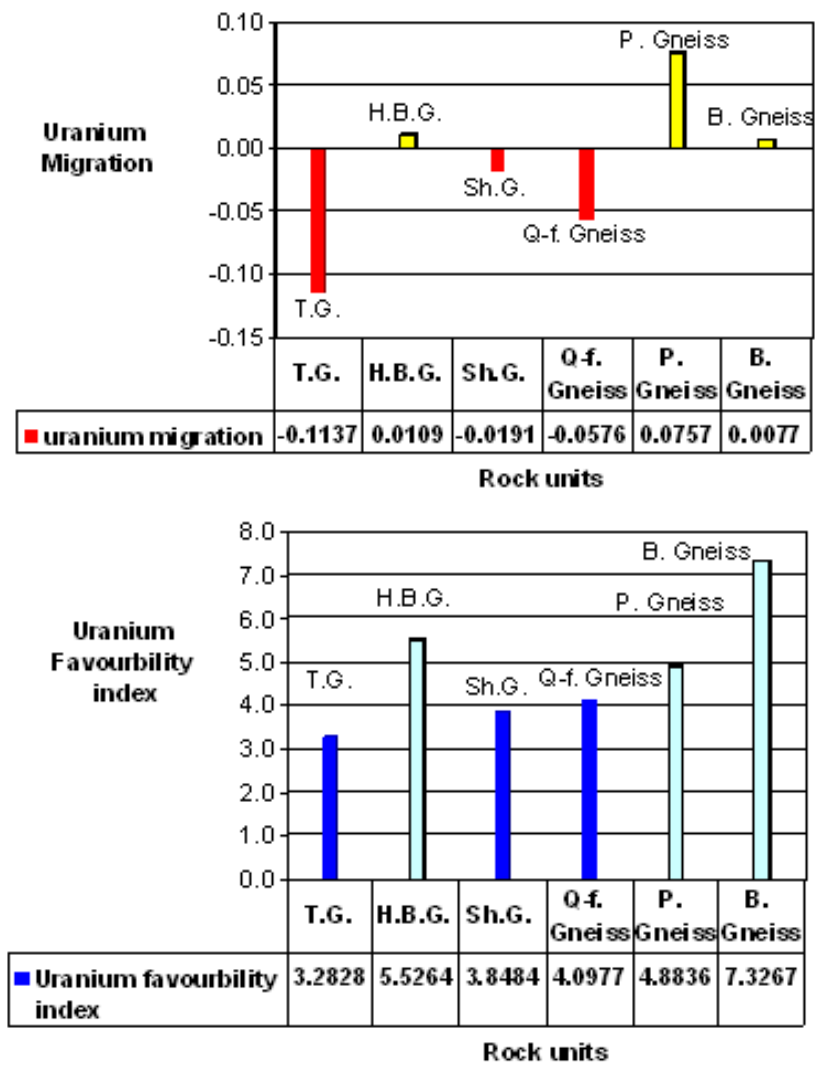

Rock units

\section{Multi-Variate Statistical Analysis}

a- Principal components and factor scores:

The principal component analysis (PCA) is one of the simplest multivariate methods. This method is designed to reduce the number of transformed variables, by means, to remove the influence of the less important components in order to bring out the more important components [30], [31] and [32].

When measuring only two radioelement variables, such as uranium and thorium in a studied site, it is easy to plot this data and to visually assess the correlation between these two items. However, in a typical spectrometric survey; the expression of hundreds of different variables measurements (radioelements and its ratios) across many conditions such as variety of rock units or structural patterns in the study area. Therefore, it becomes impossible to make a visual inspection of the relationship between these variables or conditions in such a multi-dimensional matrix. One way to make sense of this data is to reduce its dimensionality. By projecting data from a higher dimension to a lower dimensional manifold such that the error incurred by reconstructing the data in the higher dimension is minimized. Several data decomposition techniques are available for this purpose: Principal Components Analysis (PCA) is among these techniques that reduces the data into two dimensions.

If the number of measured stations is 374 in 7 different variables, these values could form a matrix of 7 x 374 measurements. Now imagine that each of these 374 stations is plotted in a multi-dimensional on a scatter plot consisting of 7 axes, 1 for each variable. The result is a cloud of values in multi-dimensional space. To characterize the trends exhibited by this data, PCA extracts directions where the cloud is more extended. For instance, if the cloud is shaped like a football, the main direction of the data would be a midline or axis along the length of the football. This is called the first component, or the principal component. PCA $\mathrm{A}_{1}$ will then look for the next direction, orthogonal to the first one, reducing the multidimensional cloud into a two-dimensional space. The second principal component $\mathrm{PCA}_{2}$ would be the axis along the football width.

PCA can offer an effective method for noise removal. Since there is a high level of correlation between TC, K, U and Th, these end up in the lower order components. The noise, on the other hand, does not correlate between channels and can be partially removed by spatially filtering (low-pass filtering) the higher order components before doing the inverse PCA transform. Measurements which include many variables are commonly encountered in mineral exploration and geological mapping. PCA and Factor scores analyses determine the significance of the correlated variables. In the First Principal Component, there are seven variables, the first three have an account of $97 \%$ of the total variance and the other four components may be reasonably ignored.

In the study area, the first principal component analysis $\left(\mathrm{PCA}_{1}\right)$ is computed using the following formula [30] and [31]: 
$P C A_{1}=0.21 * K+0.26 *(T C)+0.26 *(e T h)+0.1 *(e T h / K)+0.23 *(e U)-0.08(e U / K)-0.13 *(e U / e T h)$

In this case, there are five positive weights of the variables $\mathrm{K}, \mathrm{TC} ., \mathrm{eTh}, \mathrm{eTh} / \mathrm{K}$ and $\mathrm{eU}$ and two negative weights $\mathrm{eU} / \mathrm{K}$ and eU/eTh. The computed ( $\left.\mathrm{PCA}_{1}\right)$ is presented in the form of a contour map (Fig.9).

This map shows the spatial distribution of the radioelements in the study area. Five intermediate to high positive zones could be delineated. These zones are accompanied by different rock units which are: biotite gneiss, psammitic gneiss, quartzo-feldspathic gneiss, Umm Takha granite and El-Sheikh granite.

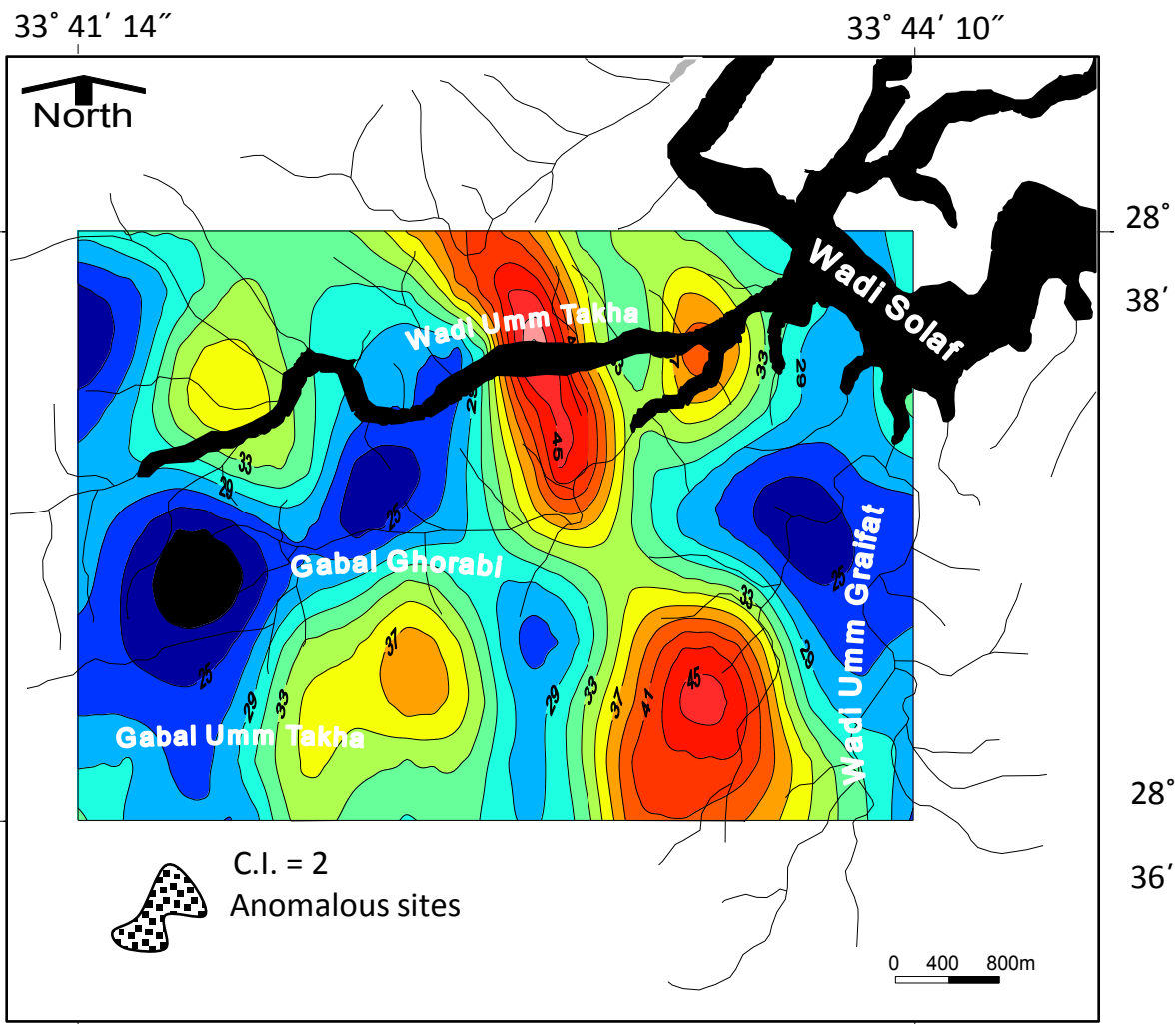

Fig.9: First principal component contour map of Solaf-Umm Takha area shows the spatial distribution of the radioelements in the study area. Five intermediate to high positive zones could be delineated. These zones are accompanied by different rock units which are: Biotite gneiss, Psammitic gneiss, Quartzofeldspathic gneiss, Umm Takha granite and El-Sheikh granite.

The Second principal component analysis of the study area $\left(\mathrm{PCA}_{2}\right)$ is computed using the following formula:

$$
P C A_{1}=0.24 * K+0.03 *(T C)+0.08 *(e T h)+0.29 *(e T h / K)-0.13 *(e U)+0.43(e U / K)+0.34 *(e U / e T h)
$$

In this type of analysis, all the variables are positive except eU, and the three radioactive ratios have the highest positive weights. The $\left(\mathrm{PCA}_{2}\right)$ is the factor which represents the uranium distribution and its extend. Then, it is possible to get an idea about the concentration and distribution of the radioactive minerals in the study area between Wadi Umm Takha and Wadi Umm Graifat.

The $\left(\mathrm{PCA}_{2}\right)$ map (Fig.10) shows high positive zones occupying different rock units, which are: El-Sheikh granite and Quartzo-feldspathic gneiss and the Umm Takha granite. These zones reflect the increase in uranium concentrations relative to both thorium and potassium.

b- Factor scores:

The technique of factor scores was first promulgated by [33]. The factor score coefficient matrix shows the coefficients by which items $\left(\mathrm{PCA}_{1} \& \mathrm{PCA}_{2}\right)$ are multiplied to obtain factor scores. The results of this multiplication can adjust the boundaries between the different rock units on the geologic map.

In the study area the factor scores analysis could clearly define the boundaries between the biotite gneiss, psammitic gneiss and El-Sheikh granite \& Quartzo-feldspathic gneiss, (Fig.11). 


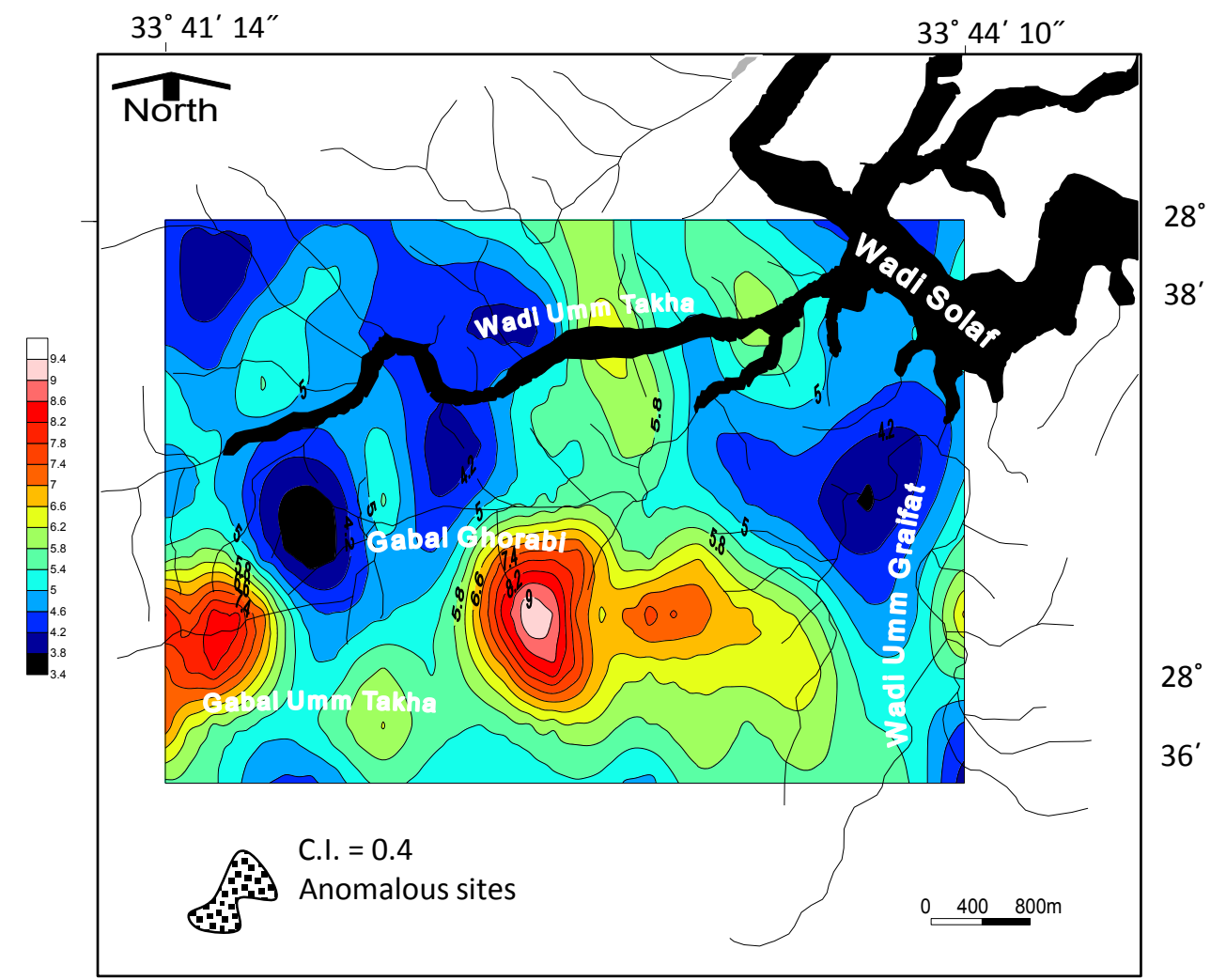

Fig.10: Second principal component contour map of Solaf-Umm Takha area shows high positive zones occupying different rock units, which are: ElSheikh granite and Quartzo-feldspathic gneiss and the Umm Takha granite. These zones reflect the increase in Uranium concentrations relative to both Thorium and Potassium.

\section{Conclusion}

1- Three analytical techniques have been applied on the measured ground gamma ray spectrometric data in Solaf-Umm Takha area, southwestern Sinai, Egypt. These techniques are: the uranium migration (in \& out), the multi-variate analysis (including the principal components) and the factor scores.

2- Different radioelements maps, including T.C., eU, eTh \& $\mathrm{K} \%$, have been constructed to show the surface distribution of these radioelements relative to the different rock units. Moreover, the uranium migration analysis indicates that the Umm Takha granite, which has the highest uranium outward migration rate, is the main uranium-source rock in the study area. However, the psammitic gneiss which has the highest Uranium inward migration rate is considered as the main uranium-received rock in the study area.

3- The source rocks of uranium such as Umm Takha granite, quartzo-feldspathic gneiss and El-Sheikh granite have the lower uranium favorability indices, while the received rocks of uranium such as psammitic gneiss, hornblende biotite gneiss and biotite gneiss have the higher uranium favorability indices. The assumption was corrected according to favorability index technique on igneous and metamorphic environments where low values of eU/eTh which indicate Uranium depletion from source rocks may validate such an interpretation in igneous and metamorphic terrains.

4- Integration of the obtained radioelements distribution maps and statistical analysis could produce a map containing promising sites for high Uranium potentiality (Fig.12). This map also shows a structural control relationship between the rock units boundaries estimated from factor scores analysis, Uranium priority potentialities estimated from principal components analysis and Uranium favorability indices with the major structure, the thrust fault which is the controlling item in fractures framework in the study area.

5- The migration history of Uranium in Solaf-Umm Takha area is identified by the integration of Uranium migration and Uranium favorability index results that declared the eastern and southern parts of study area are the start point of Uranium migration to the western and northern parts of the study area and that means from the high relief mountainous region to the drainage divide of Solaf-Umm Takha Wadis.

6- Exploration for uranium should not be restricted to the source rocks, but is recommended to extend to the received rocks in which it may host considerable concentrations of uranium. 

$33^{\circ} 41^{\prime} 14^{\prime \prime} 33^{\circ} 44^{\prime} 10^{\prime \prime}$

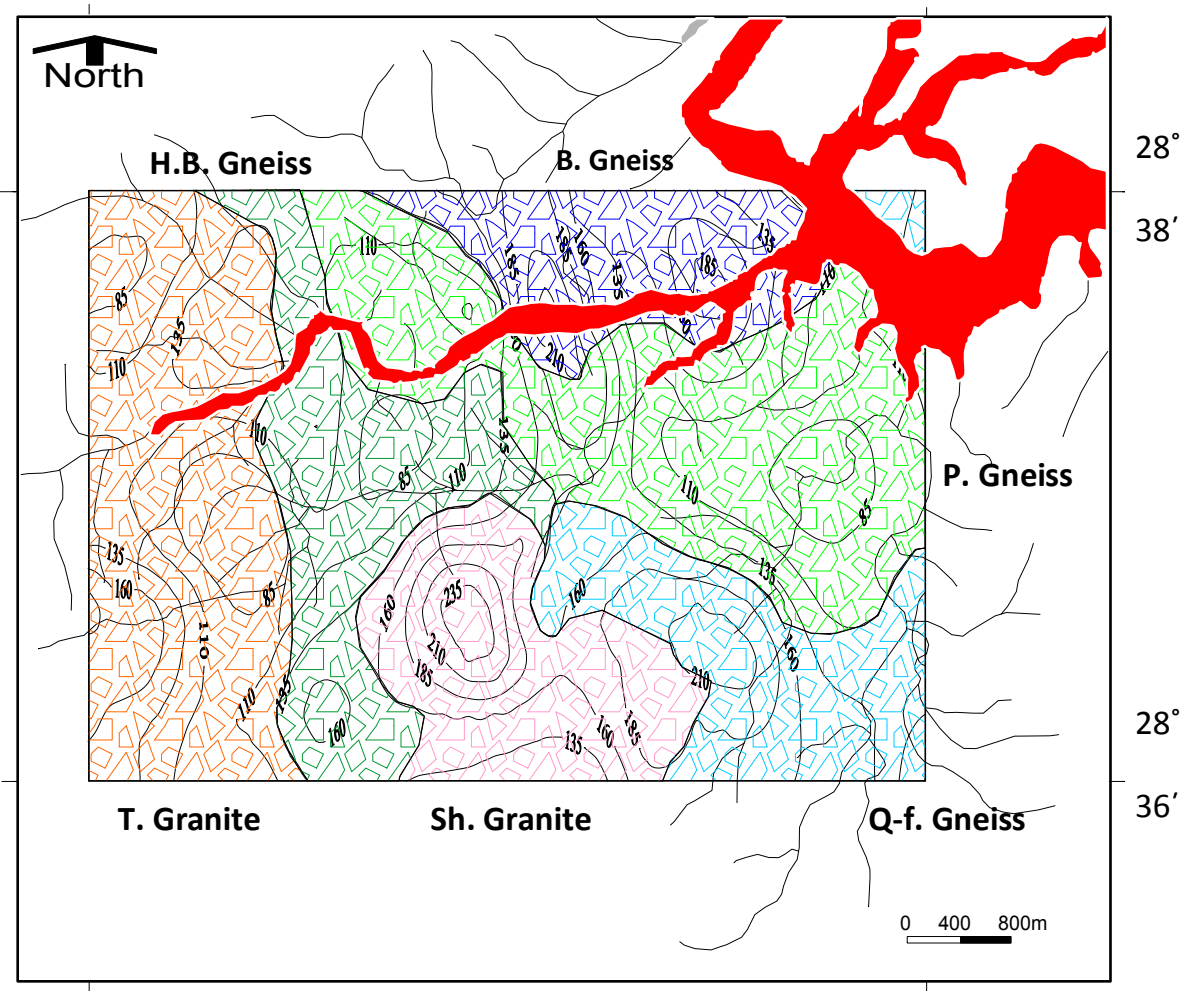

Fig.11: Rock boundaries in Solaf-Umm Takha area as deduced from factor scores. The boundaries are well defined between Biotite gneiss \& Psammitic gneiss and El-Sheikh granite \& Quartzo-feldspathic gneiss.

$$
33^{\circ} 41^{\prime} 14^{\prime \prime} \quad 33^{\circ} 44^{\prime} 10^{\prime \prime}
$$

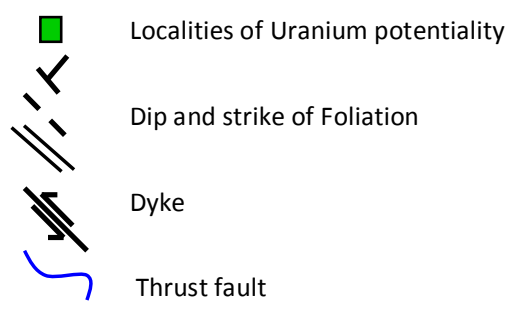

Fig.12: Promising sites for Uranium mineralization in Solaf-Umm Takha area according to integration of the obtained radioelements maps and statistical analysis containing high Uranium potentialities.

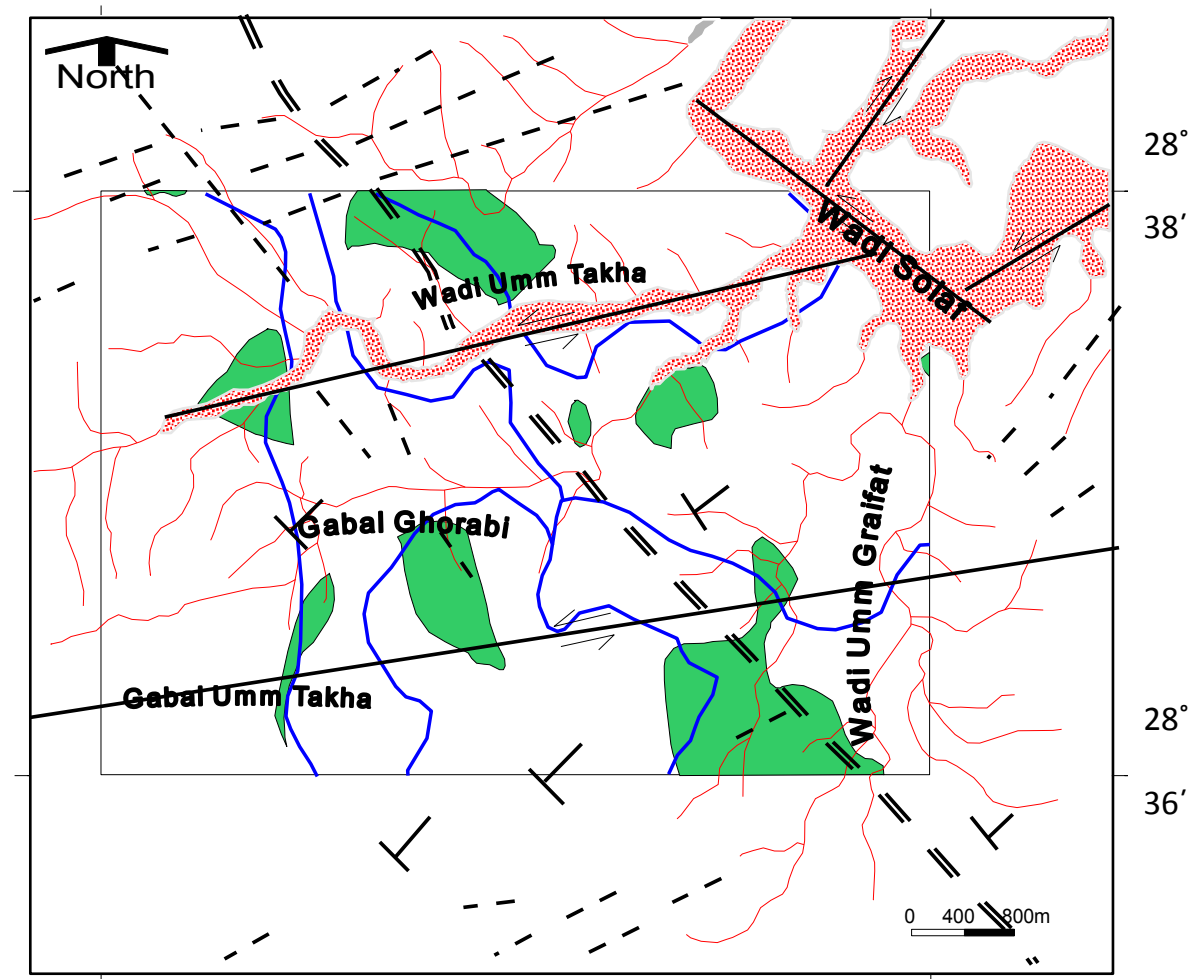




\section{References}

[1] L.M.S. Magdy, A.A. Ammar, E.M. El Kattan, I.A. El Kassass, The role of Aeroradiometry in modifying geology and identifying anomalous zones, Serbal-Nukhull area, Sinai Peninsula, Egypt. Nuclear Materials Authority. Nucl. Geophys. Vol. 9. No. 2. 1995,147168

[2] Darnley, K.L. Ford, A regional airborne Gamma-ray surveys review; in Proceedings of Exploration, 87: Third Decennial International Conference on Geophysical and Geochemical Exploration for Mineral and Groundwater, edited by G.D. Garland, Ontario, Geol. Surv. of Canada, Special, 3, 1989, 960p.

[3] W.F. Hume, The topography and geology of the Peninsula of Sinai (southeastern portion). Geological Survey of Egypt, Cairo, 1906, 280 pp.

[4] W. F. Hume, Geology of Egypt. II. The fundamental Precambrian rocks of Egypt and the Sudan: Geol. Surv. of Egypt, Cairo, Egypt, 1935,Part I, The metamorphic rocks: pp. 1-300; Part II, The later plutonic and minor intrusive rocks, pp. 301-688.

[5] J. Ball, The Geography and Geology of the West Sinai, Egypt. Egyptian Geological Survey, 1916, $219 p$.

[6] M.K. Akaad, The magmatic gneisses of Wadi Feiran, Sinai, Egypt. Assiut Science and Technology Bulletin, Assiut University, 2, $1959,211-237 \mathrm{pp}$

[7] S. El Gaby, A.M. Ahmed,. The Feiran-Solaf gneiss belt SW Sinai, Egypt. I.A., G. Bull. No.3, Vol.4, 1980, $95-105$ pp.

[8] A.A. Ahmed, Geology of the Area Around Feiran Oasis, Sinai. Ph.D. Thesis. Assiut Univ., Egypt 1970.

[9] A.A. Ahmed,. Reconsidered view on Feiran-Solaf Gneisses southwest of Sinai, Egypt. Bull. Fac. Sci. Assiut Univ. 10, 1981, 131142 .

[10] A.M. Hegazi, Structural studies on Feiran Oasis area, Central Sinai, Egypt. M.Sc. Thesis, Suez Canal Univ., Egypt. 1988, 81p.

[11] Y.M, Sultan, Tectonic setting of south Sinai metamorphic belts based on remote sensing, structural analysis and GIS. Ph.D. in geology Dept. 2011, Faculty of Science, Suez Canal University, Ismailia, Egypt.

[12] A.M. Hegazi, M.K. El-Shafei, Y.M. Sultan, Multiple deformation phases of Solaf Gneiss Belt, South Sinai Egypt. Proceedings of the 7th International Conference on Geology of the Arab World, Cairo (2004), pp. 313-320.

[13] A.M. Mehanna, F.A. Soliman, Geology and Geochemistry of west Wadi Hebran area, southwestern Sinai, Egypt. Proc. 5th Conf. Geol. Sinai Develop., Saint Catherine, 1998, pp. 113-131.

[14] Kelvin Energy Limited, report on airborne electromagnetic, magnetometer and radiometrics survey. Kettle River Area, British Colwnbia, November 1978, APPENDIX III, GAD-6 AND GSA-42 SPECIFICATIONS.

[15] P.G. Killeen, J.G. Conaway, New facilities for calibrating gamma-ray spectrometric logging and surface exploration equipment; $C I M$ Bull., Vol. 71, No. 793, 1978, pp.84-87.

[16] International Atomic Energy Agency, Radiometric reporting method and calibration in Uranium exploration: International Atomic Energy Agency Technical reports series, 1976, 174p.

[17] T.P. Mernagh, Y. Miezitis, A Review of the Geochemical Processes Controlling the Distribution of Thorium in the Earth's Crust and Australia's Thorium Resources. Geoscience Australia Record 2008/05, 48p.

[18] R.W. Boyle, Geochemical prospecting for thorium and uranium deposits. Elsevier Scientific Publishing Company, Amsterdam, 1982, $498 p$

[19] G.B. Naumov, Transportation of uranium in hydrothermal solution as a carbonate, Geochemistry, V (1), 1959, pp. 5-20.

[20] Benzing Uranium Institute, Field Gamma-ray Spectrometric Survey, No.3, 1977, 1:292, China.

[21] A. A. Hassan, B. M. Ghieth, A. F. Khalil and A. A. Nigm, Uranium favourability and its mode of migration in some rocks in the south eastern desert, Egypt. Egyptian Journal of Geology, V. 47/2, 2003, pp. 1125-1138.

[22] A. A. Hassan, B. M. Ghieth, A. F. Khalil, M. O. Elminawy, A. A. Nigm and R. M. Abdelrehim, A statistical analysis and composite images study of the airborne gamma-ray spectrometric data, Gabal Monqul area, north eastern deasert, Egypt. Proc. $3^{\text {rd }}$ International Symposium on Geophysics, Tanta, 2004, pp. 183-195.

[23] A. Abu-Deif, S.O.A. Helmy and I.E.H. Hamdy, Radioelements and Uranium Migration in Granites, El-Missikat Tunnels, Central Eastern Desert, Egypt. King Abdulaziz University, Faculty of Earth Sciences Geophysics Department, Jeddah, Kingdom of Saudi Arabia JKAU: Earth Sci., Vol. 18, 2007, pp. 89-115.

[24] W. E. Falck, D. Read, S. Black, D. Thornley, M. Siitari-Kauppi, Uranium Migration in Crystalline Rocks. European Commission, Joint Research Centre Institute for Energy. address: P.O. Box 2, NL-1755 ZG Petten, 2009. The Netherlands.

[25] D. F. Saunders and M. J. Potts, Manual for the application of NURE 1974-1977 aerial gamma-ray spectrometer data: U.S. Energy Re-search and Development Administration GJBX-13(78) Open-File Report, 1978

[26] D. F. Saunders, Characterization of uraniferous geochemical provinces by aerial gamma-ray spectrometry: Mining Engineering, v. $31,, 1979$, pp. 1715-1722.

[27] F. L. Pirkle, R. J. Beckman and H. L. Jr. Fleischhauer, A Multivariate Uranium Favorability Index Using Aerial Radiometric Data. Journal of Geology, Vol 90, , 1982, pp.109-124.

[28] Texas Instruments Inc., Study of airborne gamma-ray spectrometer data procedures Wind River Basin, Wyoming: U.S. Dept. of Energy GJBX-40(79) Open-File Report, 1979, v. 1

[29] Texas Instruments Inc., Interpretation methods test report for NURE aerial radiometric and geochemical data, v. 1-text: U.S. Dept. of Energy GJBX-137(80) Open-File Report, 1980.

[30] T.W. Anderson, An introduction to multivariate analysis 2nd edition, John Wiley and Sons, 1984,675 .

[31] B. Manly, Multivariate statistical methods: A Primer. Published by Chapman and Hall Ltd., London, , 1986, $159 \mathrm{p}$

[32] S. Raychaudhuri, , J.M. Stuart and R.B. Altman, Principal components analysis to summarize microarray experiments: application to sporulation time series. Pacific Symposium on Biocomputing (2000).

[33] C. Spearman, General intelligence objectively determined and measured. American Journal of Psychology 15, , 1904, pp. 201-293. 